\title{
Electrochemical and Metallurgical Effect of Sn Addition on Al in Al-NaCl Batteries
}

\author{
Youssef Gouale*, Salma Khatbi and Mohamed Essahli \\ Univ. Hassan 1, Laboratory of Applied Chemistry and Environment, Faculty of Science and \\ Technology, P.O. Box 5777, Settat, Morocco
}

Received December 27, 2016; accepted September 7, 2017

\begin{abstract}
The purpose of our work is to improve the corrosion and mechanical shocks resistance of aluminium in the batteries, we have chosen tin as an element of addition by combining it with the aluminum and forming an Al-Sn alloy. By means of potentiodynamic polarization, electrochemical impedance spectroscopy, hardness evolution and optical microscopy, we have been able to study the effect of the tin addition on the corrosion of aluminum in $\mathrm{NaCl}$ as well as on its hardness and crystalline structure. We have also studied the influence of the electrolyte's concentration in the battery $(\mathrm{NaCl})$ and of temperature on the corrosion resistance of aluminum. The results obtained showed that the addition of tin have reduced significantly the corrosion rate of aluminum and increase its hardness. This means that the lifetime and the performance of the battery will be increased as well.
\end{abstract}

Keywords: battery, corrosion, inhibition, $\mathrm{Al}-\mathrm{Sn}$ alloys, $\mathrm{NaCl}$.

\section{Introduction}

Aluminum is becoming more and more a subject of many researches. The aim of those researches is to develop $\mathrm{Al}$ anodes that can work well in an alkaline environment and to develop a battery based of aluminum. This metal is known by its low cost, its lightness and especially its capacity, its high energy density and its negative potential in open circuit [1-3]. However, and like any other metal, aluminum has disadvantages which hinder the ability of researchers to use pure aluminum as anodes in the $\mathrm{Al}-\mathrm{NaCl}$ battery. Among these disadvantages, it is found that pure aluminum is very reactive when it's in a direct contact with an alkaline electrolyte such as $\mathrm{NaCl}$. This high reactivity is reflected by an intense corrosion of aluminum by forming a layer of oxide containing predominantly $\mathrm{Al}_{2} \mathrm{O}_{3}$; this layer reduces, strongly, the capacity of the aluminum, which entails a loss in its potential when it is in an anodic polarization [4]. In order to overcome all these obstacles that prevent the use of pure aluminum in the batteries, many

\footnotetext{
* Corresponding author. E-mail address: gouale.youssef@gmail.com
} 
studies have been made to find aluminum based alloys that will be able to inhibit or at least decrease the corrosion rate of aluminum, and therefore to improve the capacity and the lifetime of the $\mathrm{Al}-\mathrm{NaCl}$ or Al-air batteries. D. D. Macdonald et al. [5] have found that some metals such as $\mathrm{Zn}, \mathrm{Bi}, \mathrm{Te}, \mathrm{In}, \mathrm{Ga}, \mathrm{Pb}, \mathrm{P}$, and $\mathrm{Ti}$ (or combinations of these) have a very positive effect on aluminum corrosion, since they reduce its corrosion rate if they are added in very low contents that don't exceed, generally, $0.5 \%$.

Other Researchers [6-11] have found that the elements $\mathrm{Ga}, \mathrm{In}, \mathrm{Ti}, \mathrm{P}, \mathrm{As}, \mathrm{Sb}$ are good corrosion inhibitors for $\mathrm{Al}$ in alkaline or neutral chloride mediums. They have also found that the most effective elements are those which can be, in their pure state, poor catalytic surfaces for the hydrogen evolution. This suggests that they migrate through surface diffusion toward surfaces that have active sites for hydrogen evolution, or that they dissolve in the electrolyte only to precipitate on the surface of aluminum in the form of a semi-continuous or continuous film.

Prior to this work, we studied the effect of the addition of phosphoric acid and its salt $\mathrm{K}_{2} \mathrm{HPO}_{4}$ into the corrosive electrolyte of $4 \mathrm{M} \mathrm{H}_{2} \mathrm{SO}_{4}$ on the corrosion resistance of lead. The obtained results were very promising, the corrosion and passivation rates were significantly reduced [12].

The objective of this work is to study the effect of $\mathrm{Sn}$ addition on the corrosion rate of $\mathrm{Al}$ in $0.6 \mathrm{M} \mathrm{NaCl}$ and on its hardness in order to obtain an alloy which can very well be used as anode in the battery, be resistant to corrosion, to heat and mechanical shocks.

\section{Experimental procedures Elaboration of alloys}

Alloys are melted at $70{ }^{\circ} \mathrm{C}$ in a crucible with $4 \mathrm{~cm}$ in diameter. The choice of a good melting crucible is not always simple, given the wide range of materials, forms and capabilities. When it comes to choosing a crucible that will allow a good homogeneity of our elements and that will have a good resistance to high temperatures, it is important to consider how and for how long it will be used. After fusion and cooling until the total solidification is achieved, the ensemble (alloy-crucible) is soaked in water.

We used an electrode formed of Al-Sn alloy with different contents of tin $(0.2 \%$, $0.4 \%$ and $0.6 \%$ ) in the form of a disk of $1 \mathrm{~cm}^{2}$. In order to obtain reliable and reproducible results, the working electrode undergoes, before each test, polishing with different abrasive papers 400, 600 and 1200. Then, they are rinsed with distilled water and dried.

The alloys are prepared from metals of $99.5 \%$ purity. The contents of $\mathrm{Sn}$ and the melting temperature are chosen in accordance with the phase diagram of the binary Al-Sn system represented in Fig. 1. The binary system of Al-Sn presents an eutectic bearing at $228.3{ }^{\circ} \mathrm{C}$. The composition of the eutectic liquid is approximately $0.5 \%$ by weight of tin.

Before elaborating the Al-Sn alloys, we analyzed the chemical composition of pure $\mathrm{Al}$; after the elaboration of the alloys, we analyzed their chemical composition, including the impurities. For this, we used the The Thermo Scientific Niton XL5 which is a spectrometer of X-ray fluorescence. It's the 
newest and the faster analyzer in the market today, giving fast and accurate results. The chemical composition of the prepared alloys is represented by the Tab. 1. It is a punctual analyze, therefore, the measurements were made at one point of each alloy.

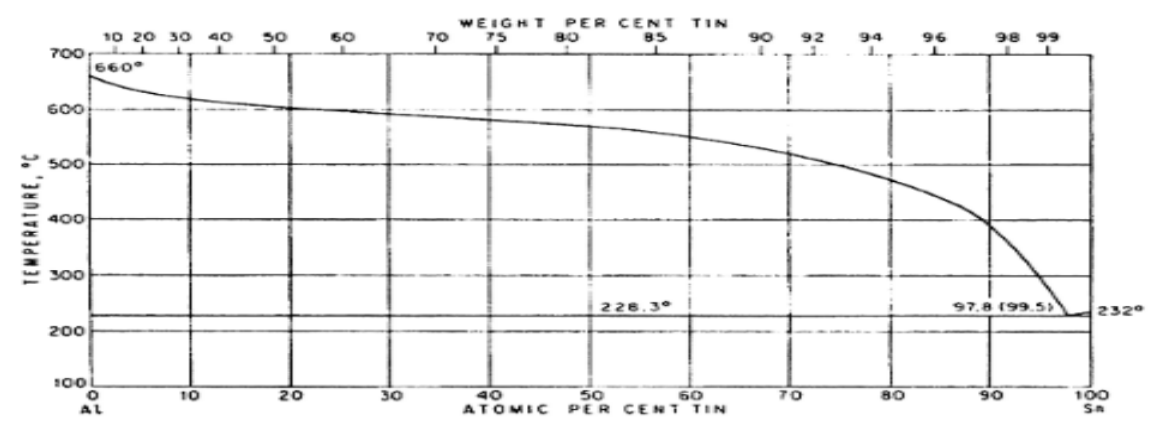

Figure 1. Phase diagram of the binary Al-Sn system.

Table 1. Chemical composition of $\mathrm{Al}$ and $\mathrm{Al}-\mathrm{Sn}$ alloys.

\begin{tabular}{cccccccccccc}
\hline $\begin{array}{c}\text { Sn } \\
\text { added } \\
(\%)\end{array}$ & $\begin{array}{c}\mathbf{A l} \\
(\boldsymbol{\%})\end{array}$ & $\begin{array}{c}\mathrm{Sn} \\
(\boldsymbol{\%})\end{array}$ & $\begin{array}{c}\mathbf{C r} \\
(\boldsymbol{\%})\end{array}$ & $\begin{array}{c}\mathbf{P} \\
(\boldsymbol{\%})\end{array}$ & $\begin{array}{c}\mathrm{Ti} \\
(\boldsymbol{\%})\end{array}$ & $\begin{array}{c}\mathrm{Si} \\
(\boldsymbol{\%})\end{array}$ & $\begin{array}{c}\mathbf{C u} \\
(\boldsymbol{\%})\end{array}$ & $\begin{array}{c}\mathbf{P b} \\
(\boldsymbol{\%})\end{array}$ & $\begin{array}{c}\mathbf{M n} \\
(\boldsymbol{\%})\end{array}$ & $\begin{array}{c}\mathbf{M g} \\
(\boldsymbol{\%})\end{array}$ & $\begin{array}{c}\mathbf{Z n} \\
(\boldsymbol{\%})\end{array}$ \\
\hline $\mathbf{0}$ & 99.500 & ---- & 0.050 & ---- & ---- & 0.280 & 0.050 & ---- & 0.030 & 0.020 & 0.070 \\
\hline $\mathbf{0 . 2}$ & 99.680 & 0.200 & ---- & 0.001 & 0.007 & 0.050 & ---- & 0.030 & ---- & ---- & 0.025 \\
\hline $\mathbf{0 . 4}$ & 99.550 & 0.400 & 0.016 & ---- & ---- & ---- & 0.032 & ---- & ---- & ---- & ---- \\
\hline $\mathbf{0 . 6}$ & 99.350 & 0.599 & ---- & 0.004 & 0.0001 & 0.017 & ---- & ---- & 0.020 & 0.0015 & ---- \\
\hline
\end{tabular}

\section{Preparation of $\mathrm{NaCl}$ solution}

The $\mathrm{NaCl}$ solutions were prepared by dissolution of $\mathrm{NaCl}$ in distilled water. The test solutions were freshly prepared before each experiment. For each analyze, the experiment was made 3 times to ensure the reproducibility of the results.

\section{Hardness}

The hardness tests were carried out by the Vickers method using a Testwell durometer under a load of $2 \mathrm{Kgf}$. Each measurement corresponds to the average of a maximum of four imprints located on a planar section corresponding to a diameter plan or perpendicular to the axis of the cylindrical sample. The sections are obtained by sawing, mechanical abrasion and then chemical polishing. Recall that the empirical relationship $\mathrm{HV}=0.3 \mathrm{R}(\mathrm{MPa})$ can be used to assess the maximum load $(\mathrm{R})$ of these alloys.

\section{Optical microscopy}

The physical properties of the quenched solid solutions of aluminum alloys are evolving from room temperature. The hardening mechanisms are continuous/discontinuous transformations. This temperature corresponds to 0.5 Tf (melting temperature of the alloy). We know that from 0.4 up to $0.5 \mathrm{Tf}$, the elements of the alloy can diffuse. In the case where the kinetics of the discontinuous transformation are rapid at room temperature, we use the original technique developed by Hilger [13] in order to be able to observe the structure before any transformation. For our alloys, the sample is polished, soaked in a 
chemical solution consisting of one part of $30 \% \mathrm{H}_{2} \mathrm{O}_{2}$ and three parts of glacial acetic acid. The solution temperature is $-50{ }^{\circ} \mathrm{C}$.

\section{Electrochemical techniques}

The electrochemical measurements have been carried out in a cell of 3 electrodes consisting of a saturated calomel electrode (reference), a platinum electrode (auxiliary) and an electrode of Al-Sn (working electrode). Before each test, the alloy is left under an open current for 5 minutes to achieve a stable state. For this study, we used 2 types of electrochemical techniques: potentiodynamic polarization and electrochemical impedance spectroscopy (EIS). The potentiodynamic polarization was made by sweeping the potential at a speed of 5 $\mathrm{mV} / \mathrm{s}$ from - 1500 to $0 \mathrm{mV}$. We obtained the different kinetic parameters such as the corrosion current density $\left(\mathrm{I}_{\text {corr }}\right)$, the corrosion potential $\left(\mathrm{E}_{\text {corr }}\right)$ and the Tafel slopes (anodic $\beta_{\mathrm{a}}$ ) and cathodic $\left(\beta_{\mathrm{c}}\right)$. The corrosion current density has been measured by extrapolation of the straight lines of Tafel. The measurements of the electrochemical impedance spectroscopy were performed using a margin of frequency ranging from $30 \mathrm{MHz}$ to $50 \mathrm{kHz}$ at the corrosion potential. For the analysis, we used the device 10 VoltaLab model (PGZ100) connected to a HP computer with the software VoltaMaster 4 and OriginLab for the data acquisition.

\section{Results and discussion Hardness}

Fig. 2 shows the hardness evolution of Al-0.2\%Sn, Al-0.4\%Sn and Al-0.6\%Sn oversaturated hardened cast alloys at $20{ }^{\circ} \mathrm{C}$. After analyzing the hardness curves, we note that the initial value of the hardness $(11.11 \mathrm{HV})$ is very high in comparison with that of the basic element which is pure aluminum $(5 \mathrm{HV})$. The hardness is higher due to the transformations that take place during the solidification of the alloy.

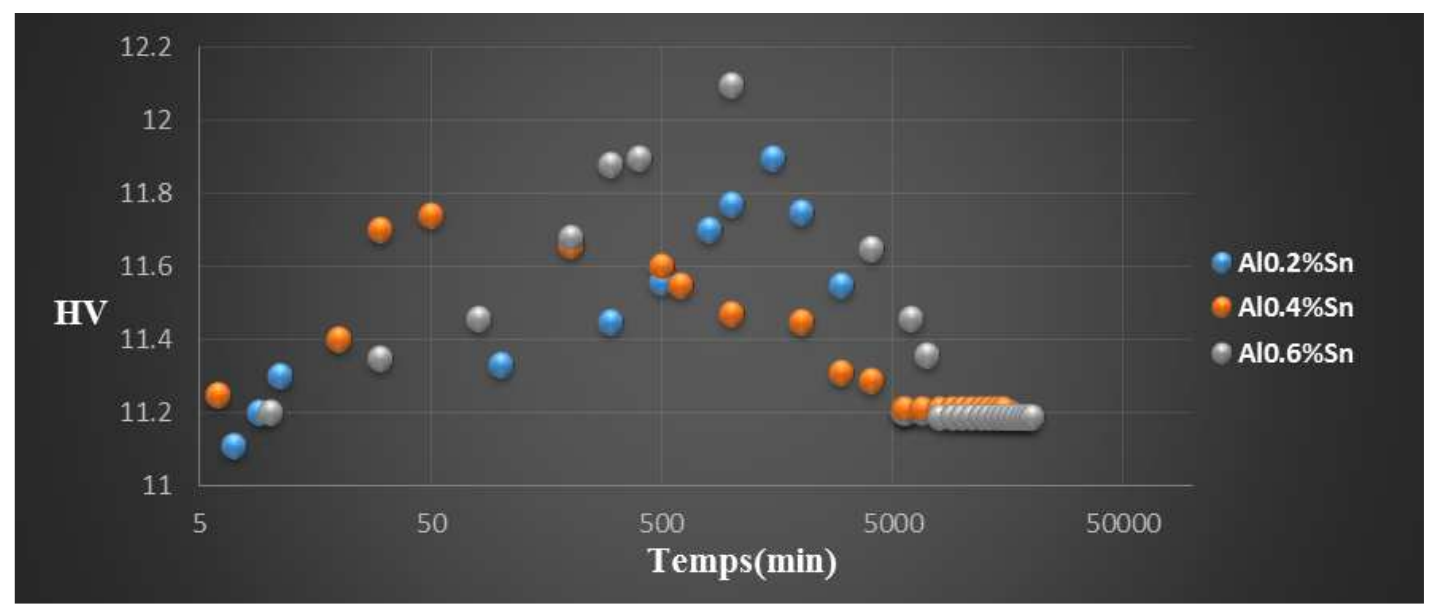

Figure 2. Hardness evolution in function of time at room temperature of Al-Sn cast alloys immerged in water. 
For the 3 alloys at $20{ }^{\circ} \mathrm{C}$, the maximum hardness infringement is approximatly $12 \mathrm{HV}$. At the end of 1 day we note a slight decrease. After 15 days, the hardness becomes stable at $11.19 \mathrm{HV}$. For the $2^{\text {nd }}$ alloy $0.4 \%$, with an initial value of the hardness $(11.25 \mathrm{HV})$ at the same conditions and at room temperature, the maximum hardness reached is $11.74 \mathrm{HV}$. At the end of $50 \mathrm{~min}$ we note a slight decrease. After 20 days the hardness becomes stable at $11.21 \mathrm{HV}$ for the last alloy Al-0.6\% Sn, being its initial value $11.20 \mathrm{HV}$ at room temperature $\left(20{ }^{\circ} \mathrm{C}\right)$, reaching a maximum of the order of $12 \mathrm{HV}$. At the end of 3days, we note a slight decrease. After that, the hardness becomes stable at $11.19 \mathrm{HV}$. This shows that continous precipitation happens simultaneously with this discontinuous reaction.

\section{Optical microscopy}

Fig. 3 shows the visualization by optical microscopy of the precipitates aligned in the discontinuous precipitation characterizing the overaging. The analysis carried out in the regions concerned by the overaging, shows that the precipitates are fully trained of Sn. However, analyzes of the interlamellar areas are much depleted in tin and its concentration remains the same throughout the matrix.

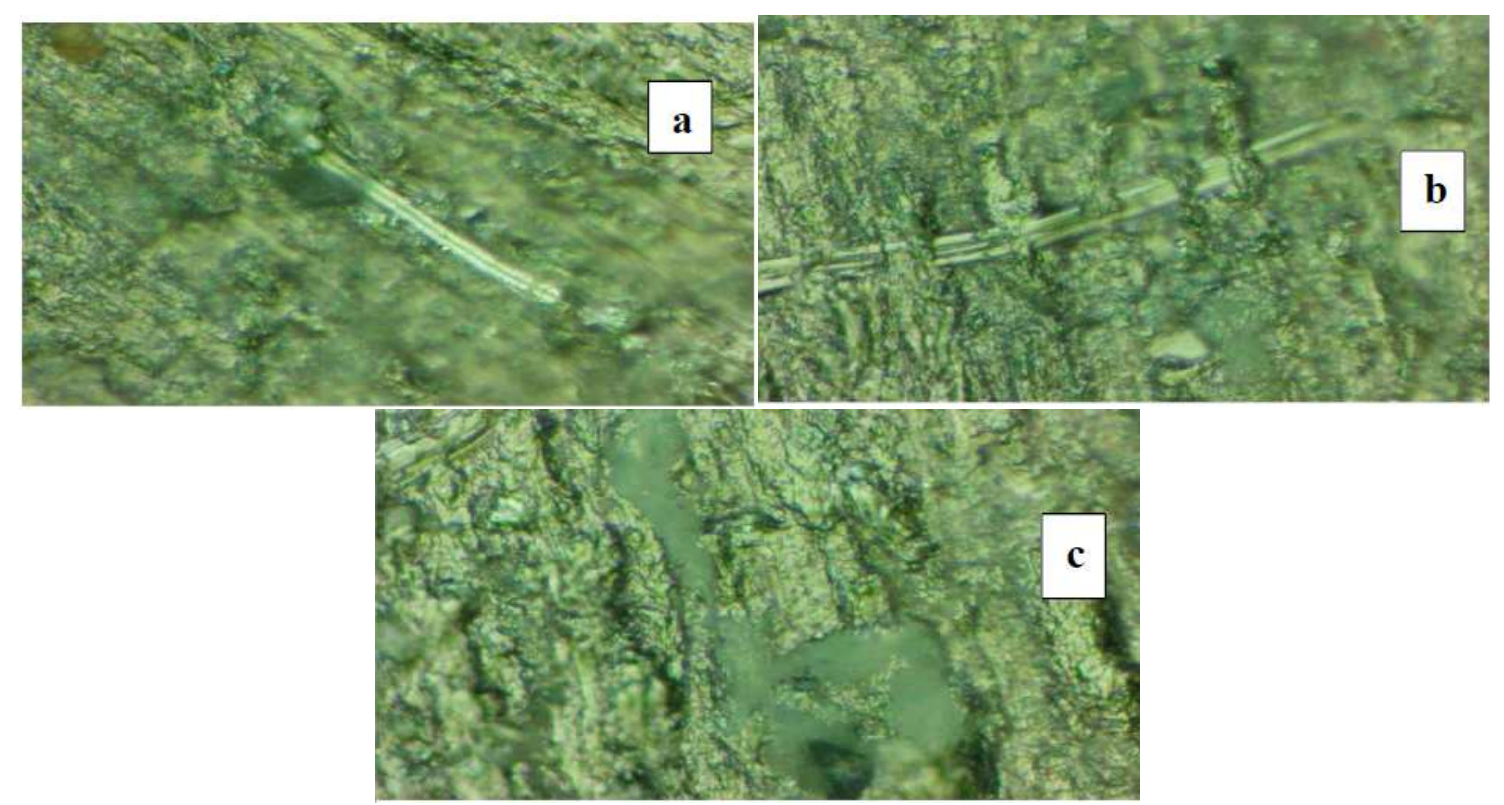

Figure 3. Discontinuous precipitation (overaging) of the cast alloys Al-0.2\%Sn (a), Al$0.4 \% \mathrm{Sn}$ (b) and $\mathrm{AL}-0.6 \% \mathrm{Sn}$ (c) at $20^{\circ} \mathrm{C}$ after 1 month of aging.

\section{Potentiodynamic polarization}

Effect of Sn concentration on Al corrosion

The anodic and cathodic polarization diagrams of the Al-Sn alloys (with different contents of $\mathrm{Sn}$ ) in $\mathrm{NaCl} \quad 0.6 \mathrm{M}$ are represented in Fig. 4. The intersection point of the Tafel lines gives the corrosion current density $\left(\mathrm{I}_{\text {corr }}\right)$. The obtained polarization parametrs $\mathrm{I}_{\text {corr }}, \mathrm{E}_{\mathrm{corr}}, \beta_{\mathrm{a}}$ and $\beta_{\mathrm{c}}$ are presented in the Table 2 .

After analyzing the results of potentiodynamic polarization presented in Fig. 4 and Table 2, we notice that, ranging from the most negative potential to more positive potentials, the I-E curves begin with an intense decrease of the current density corresponding to the hydrogen evolution reaction. This decrease is 
followed by a peak of potential at $-1320 \mathrm{mV} / \mathrm{ECS}$ which is related to the potential where the aluminum undergoes an oxidation reaction. After this peak, the current stabilizes by forming a bearing corresponding to the passivation process which goes from $-1.2 \mathrm{~V}$ to $-0.8 \mathrm{~V}$ and in which aluminum is protected by a film formed by the product of the corrosion, $\mathrm{Al}_{2} \mathrm{O}_{3}$, which covers the surface of the metal resulting in preventing any contact between the electrolyte and the aluminum. Beyond $-0.8 \mathrm{~V}$, the current density increases again, indicating the degradation of the $\mathrm{Al}_{2} \mathrm{O}_{3}$ film and that the oxygen evolution reaction is taking place in the solution.

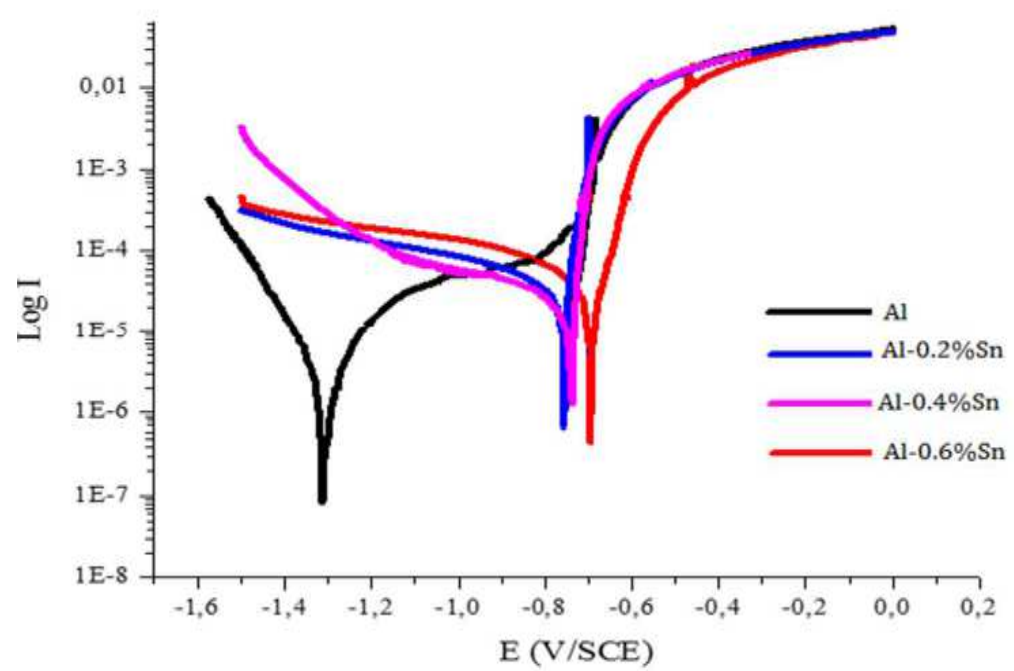

Figure 4. Potentiodynamic polarization curves of the effect of $\mathrm{Sn}$ concentration on $\mathrm{Al}$ corrosion in $\mathrm{NaCl} 0.6 \mathrm{M}$ at $25{ }^{\circ} \mathrm{C}$.

Table 2. Potentiodynamic polarization parameters of the effect of Sn concentration on $\mathrm{Al}$ corrosion in $\mathrm{NaCl} 0.6 \mathrm{M}$ at $25^{\circ} \mathrm{C}$.

\begin{tabular}{ccccc}
\hline Alloy & $\mathbf{E}_{\text {corr }}(\mathbf{m V} / \mathbf{E C S})$ & $\mathbf{I}_{\text {corr }}\left(\boldsymbol{\mu A} / \mathbf{c m}^{2}\right)$ & $\boldsymbol{\beta}_{\mathbf{a}}$ & $\boldsymbol{\beta}_{\mathbf{c}}$ \\
\hline Pure Al & -1320 & 11.01 & -152 & 86 \\
\hline Al-0.2\%Sn & -774 & 6.13 & -149 & 53 \\
\hline Al-0.4\%Sn & -721 & 5.42 & -160 & 68 \\
\hline Al-0.6\%Sn & -695 & 4.10 & -157 & 74 \\
\hline
\end{tabular}

The polarization curves represented in Fig. 4 as well as the parameters in Table 2 show, clearly, that the addition of tin has a pronounced influence on the corrosion of aluminum in $0.6 \mathrm{M} \mathrm{NaCl}$ at $25^{\circ} \mathrm{C}$. According to the polarization curves, it can be noted that after the addition of $\mathrm{Sn}$, the polarization curves are shifted to more positive potential, which is proven by the polarization parameters in Table 2, since it can be seen that the corrosion potential $\mathrm{E}_{\text {corr }}$ went from $-1320 \mathrm{mV} / \mathrm{ECS}$ for pure Al to $-695 \mathrm{mV} / \mathrm{ECS}$ for $\mathrm{Al}-0.6 \% \mathrm{Sn}$. This shift means that the metal undergoes a protection against corrosion. This protection is also reflected by the decrease in the corrosion current density, $\mathrm{I}_{\text {corr, }}$, which goes from $11.01 \mu \mathrm{A} / \mathrm{cm}^{2}$ for pure Al to $4.10 \mu \mathrm{A} / \mathrm{cm}^{2}$ for $\mathrm{Al}-0.6 \% \mathrm{Sn}$. This means that the corrosion rate of aluminum decreases and, therefore, its resistance to the corrosion increases after the addition of $\mathrm{Sn}$. 


\section{Effect of temperature on the corrosion of Al-Sn alloys}

Within the battery, the temperature may rise up to $80{ }^{\circ} \mathrm{C}$ and it is for this reason that we found it necessary to study the influence of the temperature on the corrosion of our alloys.

Fig. 5 represents the potentiodynamic polarization curves of pure Al and of AlSn alloys and Table 3 represents their corresponding parameters.
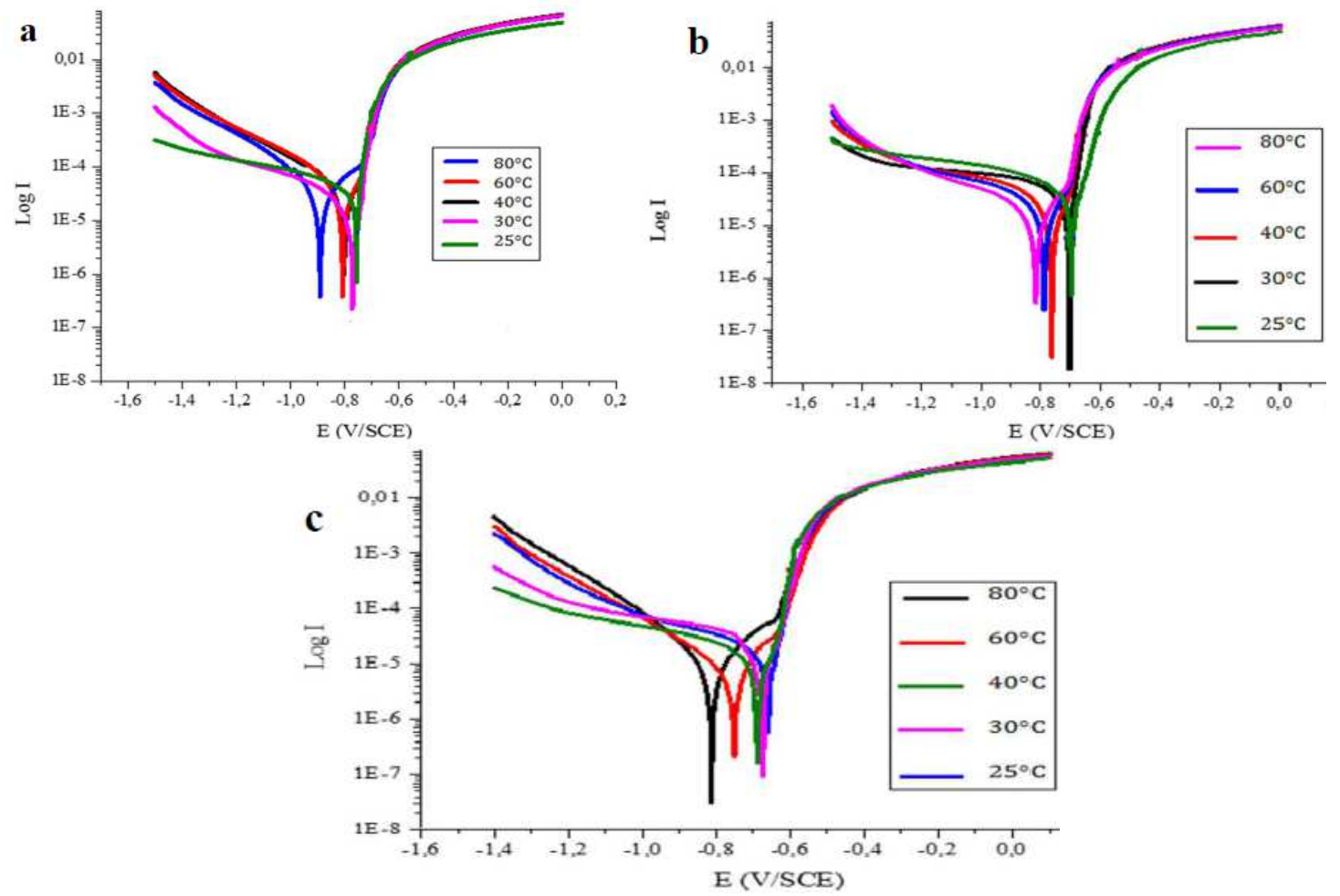

Figure 5. Potentiodynamic polarization curves of the temperature effect on Al- $0.2 \% \mathrm{Sn}$ (a), Al-0.4\% Sn (b) and Al-0.6\%Sn (c) alloys in $0.6 \mathrm{M} \mathrm{NaCl}$.

According to the obtained results, it can be noted that the increase in temperature did not have a very significant influence on the corrosion resistance of the alloys Al- $0.2 \% \mathrm{Sn}, \mathrm{Al}-0.4 \% \mathrm{Sn}$ and $\mathrm{Al}-0.6 \% \mathrm{Sn}$. The only change that seems to us pronounced is in the case of the alloy $\mathrm{Al}-0.6 \% \mathrm{Sn}$ when the temperature increases up to $80{ }^{\circ} \mathrm{C}$, where the corrosion potential decreases from -695 to $-804 \mathrm{mV} / \mathrm{ECS}$. However, the corrosion current does not change as much as the potential. And it is for this reason that we can conclude that the temperature did not influence too significantly the corrosion of Al-Sn alloys.

\section{Effect of the NaCl concentration on the corrosion of Al-Sn alloys}

According to the polarization curves and their parameters represented, respectively, by Fig. 6 and Table 4, we note that the increase of the $\mathrm{NaCl}$ concentration slightly influence the corrosion of Al-Sn alloys, since it can be clearly seen that the corrosion potential in all the alloys shifts a little toward more negative areas with the increase in the $\mathrm{NaCl}$ concentration. As well as the corrosion current density increases a little with the increase of the concentration. This can be explained by the fact that $\mathrm{NaCl}$ led to the oxidation of the surface of 
aluminum and the formation of the alumina $\mathrm{Al}_{2} \mathrm{O}_{3}$. Therefore, logically, the higher the concentrations of $\mathrm{NaCl}$, the more molecules react with $\mathrm{Al}^{2+}$ and more molecules of $\mathrm{Al}_{2} \mathrm{O}_{3}$ are formed.

Table 3. Polarization parameters of the temperature effect on Al- $0.2 \% \mathrm{Sn}$ (a), Al$0.4 \% \mathrm{Sn}$ (b) and $\mathrm{Al}-0.6 \% \mathrm{Sn}$ (c) alloys in $0.6 \mathrm{M} \mathrm{NaCl}$.

\begin{tabular}{cccccc}
\hline \multirow{2}{*}{ Alloy } & Temperature $\left({ }^{\mathbf{C}} \mathbf{C}\right)$ & $\mathbf{E}_{\mathbf{c o r r}}(\mathbf{m V} / \mathbf{E C S})$ & $\mathbf{I}_{\mathbf{c o r r}}\left(\boldsymbol{\mu} \mathbf{A} / \mathbf{c m}^{2}\right)$ & $\boldsymbol{\beta}_{\mathbf{a}}(\mathbf{m V})$ & $\boldsymbol{\beta}_{\mathbf{c}}(\mathbf{m V})$ \\
\hline \multirow{4}{*}{ Al-0.2\%Sn } & 25 & -774 & 6.13 & -149 & 53 \\
& 30 & -779 & 6.21 & -151 & 54 \\
& 40 & -799 & 6.37 & -153 & 57 \\
& 60 & -801 & 6.40 & -154 & 55 \\
$\mathbf{A l - 0 . 4 \% S n}$ & 80 & -894 & 6.71 & -158 & 62 \\
\hline \multirow{4}{*}{$\mathbf{A l - 0 . 6 \% S n}$} & 25 & -721 & 5.42 & -160 & 68 \\
& 30 & -721 & 5.43 & -161 & 68 \\
& 40 & -734 & 5.57 & -165 & 70 \\
& 60 & -736 & 5.61 & -170 & 71 \\
& 80 & -740 & 5.77 & -172 & 69 \\
\hline
\end{tabular}
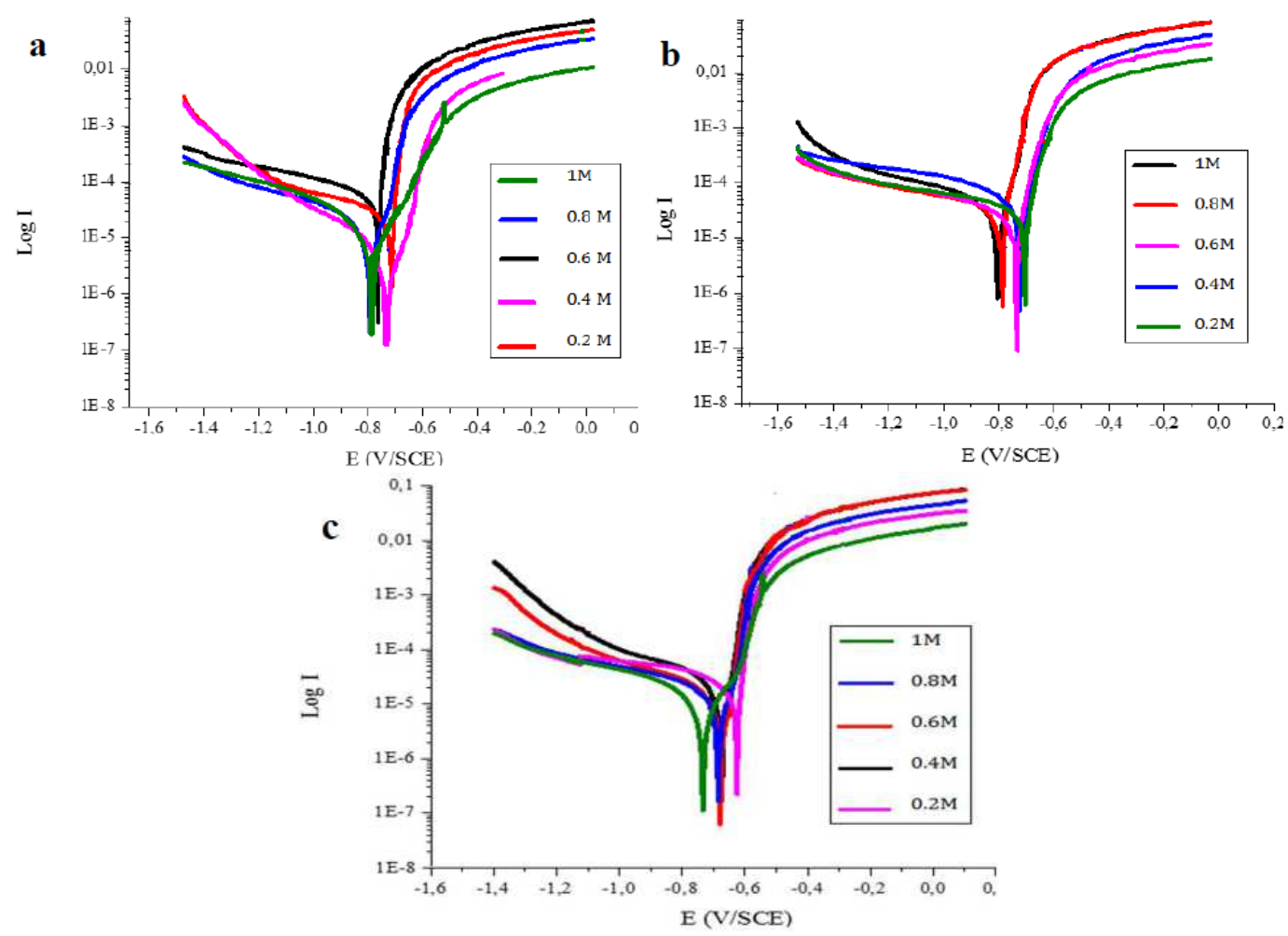

Figure 6. Polarization curves of the effect of $\mathrm{NaCl}$ concentration on the corrosion of $\mathrm{Al}-$ $0.2 \% \mathrm{Sn}(\mathrm{a}), \mathrm{Al}-0.4 \% \mathrm{Sn}(\mathrm{b})$ and $\mathrm{Al}-0.6 \% \mathrm{Sn}(\mathrm{c})$ at $25^{\circ} \mathrm{C}$. 
Table 4. Polarization parameters of the effect of $\mathrm{NaCl}$ concentration on the corrosion of Al-0.2\% Sn (a), Al-0.4\% Sn (b) and Al-0.6\% Sn (c) at $25{ }^{\circ} \mathrm{C}$.

\begin{tabular}{cccccc}
\hline Alloy & $\begin{array}{c}\text { Concentration of NaCl } \\
(\mathbf{m o l} / \mathbf{L})\end{array}$ & $\begin{array}{c}\mathbf{E}_{\mathbf{c o r r}} \\
(\mathbf{m V} / \mathbf{E C S})\end{array}$ & $\begin{array}{c}\mathbf{I}_{\mathbf{c o r r}} \\
\left(\boldsymbol{\mu} \mathbf{A} / \mathbf{c m}^{2}\right)\end{array}$ & $\begin{array}{c}\boldsymbol{\beta}_{\mathbf{a}} \\
(\mathbf{m V})\end{array}$ & $\begin{array}{c}\boldsymbol{\beta}_{\mathbf{c}} \\
(\mathbf{m V})\end{array}$ \\
\hline \multirow{3}{*}{ Al-0.2\%Sn } & 0.2 & -769 & 5.81 & -142 & 47 \\
& 0.4 & -771 & 5.84 & -145 & 49 \\
& 0.6 & -774 & 6.13 & -149 & 53 \\
& 0.8 & -779 & 6.12 & -150 & 55 \\
$\mathbf{4}$ & 1 & -780 & 6.14 & -150 & 55 \\
\hline & 0.2 & -718 & 5.40 & -159 & 68 \\
& 0.4 & -719 & 5.42 & -161 & 68 \\
& 0.6 & -721 & 5.42 & -160 & 68 \\
Al-0.4\%Sn & 0.8 & -724 & 5.48 & -159 & 67 \\
& 1 & -727 & 4.50 & -161 & 69 \\
\hline & 0.2 & -643 & 4.06 & -156 & 72 \\
& 0.4 & -676 & 4.09 & -158 & 74 \\
& 0.6 & -695 & 4.10 & -157 & 74 \\
& 0.8 & -696 & 4.40 & -157 & 73 \\
& 1 & -701 & 4.45 & -159 & 73 \\
\hline
\end{tabular}

\section{Electrochemical impedance spectroscopy (EIS)}

Effect of Sn concentration on the corrosion of Al-Sn alloys

EIS was used to determine the action mode of the compound studied, and to evaluate the dielectric properties of the passive layer; it also helps explaining the electrochemical process that develops throughout the passive layer. Thus, we used this technique to study the reaction mechanisms during the Al-Sn corrosion in $0.6 \mathrm{M} \mathrm{NaCl}$. Fig. 7 shows the Nyquist plots for pure aluminum and for Al-Sn (with different contents of $\mathrm{Sn}$ ) in $0.6 \mathrm{M} \mathrm{NaCl}$ at $25^{\circ} \mathrm{C}$. The values of the charge transfer resistance $\mathrm{R}_{\mathrm{t}}$, and those of the capacity of the double layer $\mathrm{C}_{\mathrm{dl}}$ at $\mathrm{E}_{\text {corr }}$ are listed in Table 5. The charge transfer resistance values $R_{t}$ were calculated based on the difference between impedance values at lower and higher frequencies.

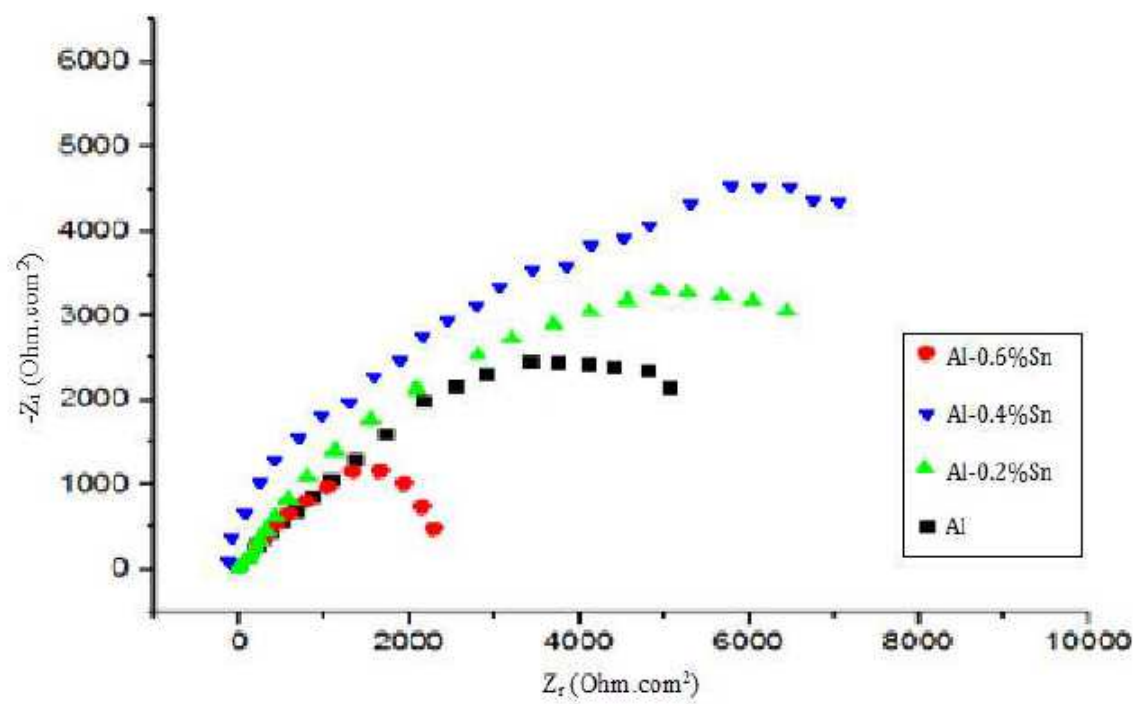

Figure 7. Nyquist representations of impedance of the $\mathrm{Sn}$ concentration effect on the Al-Sn alloys corrosion in $0.6 \mathrm{M} \mathrm{NaCl}$ at $25^{\circ} \mathrm{C}$. 
Table 5. Dielectric parameters characterizing the impedance diagrams of $\mathrm{Sn}$ concentration effect on the Al-Sn alloys corrosion in $0.6 \mathrm{M} \mathrm{NaCl}$ at $25{ }^{\circ} \mathrm{C}$.

\begin{tabular}{|c|c|c|}
\hline Alloy & $\underset{\left(\mathbf{o h m} \cdot \mathbf{c m}^{2}\right)}{\mathbf{R}_{\mathrm{t}}}$ & $\begin{array}{c}\mathrm{C}_{\mathrm{dl}} \\
\left(\mu \mathrm{F} / \mathbf{c m}^{2}\right)\end{array}$ \\
\hline Pure Al & 35.52 & 19.76 \\
\hline $\mathrm{Al}-0.2 \% \mathrm{Sn}$ & 37.91 & 16.52 \\
\hline $\mathrm{Al}-0.4 \% \mathrm{Sn}$ & 42.81 & 14.30 \\
\hline $\mathrm{Al}-0.6 \% \mathrm{Sn}$ & 43.16 & 10.64 \\
\hline
\end{tabular}

The impedance diagrams represented in Fig. 7 have the form of semi-circles, meaning that the main reaction mechanism on interface metal/electrolyte is the charge transfer.

The increase in the diameter of the half-circles indicates that, with the increase in the content of Sn, the protection of the aluminum is increased. Therefore, its corrosion resistance is increased. This is proven by the parameters of the diagrams represented in Table 5. The charge transfer resistance goes from of $35.52 \mathrm{ohm} . \mathrm{cm}^{2}$ for pure Al to $43.16 \mathrm{ohm} . \mathrm{cm}^{2}$ for Al- $0.6 \% \mathrm{Sn}$, while the capacity of the double layer decreases from $19.76 \mu \mathrm{F} / \mathrm{cm}^{2}$ to $10.64 \mu \mathrm{F} / \mathrm{cm}^{2}$, indicating that a protective layer is formed on the surface of the metal. This layer prevents further corrosion by attack of the electrolyte. This layer can be that formed of alumina $\mathrm{Al}_{2} \mathrm{O}_{3}$, which is a product of the oxidation of the aluminum. These results are in good agreement with those of the potentiodynamic polarization.

\section{Conclusion}

The results of our work can be summarized as follows:

- The electrochemical impedance spectroscopy has shown that the addition of Sn at concentrations not exceeding $0.6 \%$ reduces the corrosion rate of $\mathrm{Al}$ in $0.6 \mathrm{M}$ $\mathrm{NaCl}$.

- The potentiodynamic polarization has confirmed that the addition of $\mathrm{Sn}$ reduces, in a remarkable way, the effect of temperature on the corrosion of $\mathrm{Al}$, so our alloys will be resistant to the heat inside of the battery even if its temperature increases up to $80^{\circ} \mathrm{C}$.

- The metallurgical techniques show that the addition of Sn led to obtain much more hard alloys that pure Al and more resistant to mechanical stress since the atoms of tin change and strengthen the microstructure of aluminum.

- Al-0.2\%Sn, Al-0.4\%Sn and Al-0.6\%Sn alloys can be used as anodes in the battery $\mathrm{Al}-\mathrm{NaCl}$; they can easily replace the pure $\mathrm{Al}$ grids and lead to obtaining a battery with harder and more resistant grids to electrochemical corrosion.

\section{References}

1. Despić AR, Dražić DM, Purenović MM, et al. J Appl Electrochem. 1976;6:527-542.

2. Salkind AJ, Seiger H, Mundel A, et al. Aluminum-Air Battery System Assessment of Technical and Market Viability for Electric Vehicle 
Application. In Technical and Economic Analysis Contractors' Meeting; 1981. p. 161-166.

3. McMinn CJ, Branscomb JA. Production of Anodes for Aluminum-Air Power Cells Directly from Hall Cell Metal. Report to DOE, Subcontract No. 6124909. 1981.

4. Macdonald DD, Lee KH, Moccari A, et al. Corros. Sci. 1988;44:652-657.

5. Salisbury JD, Behrin E, Kong MK, et al. A Comparative Analysis of Aluminum-Air Battery Propulsion Systems for Passenger Vehicles. Livermore: Lawrence Livermore National Laboratory; 1980.

6. Cooper JF, Homsy RV, Landrum JH. J Electrochim Soc. 1980;127:C352C352.

7. Moden JR, Perkons G. Aluminum anode alloy for primary high power density alkaline fuel cells and batteries. US patent 4150204. 1979.

8. Zečević S, Gajić L, Despić AR, et al. Electrochim Acta. 1981;26:1625-1631.

9. El Abedin SZ, Saleh AO. J Appl Electrochim. 2004;34:331-335

10. Sammells KB. J Power Sources. 1979;4:263.

11. Hori Y, Takao J, Shomon H. Electrochim. Acta. 1985;30:1121-1124.

12. Khatbi S, Gouale Y, Lamiri A, et al. Port Electrochim Acta. 2016;34:383393.

13. Hilger JP, Boulahrouf A. Mater Charact. 1990;24:159-167. 